\title{
Considerations for the Design of a Gas Transport System for Co-location of Microalgae Cultivation with $\mathrm{CO}_{2}$ Sources
}

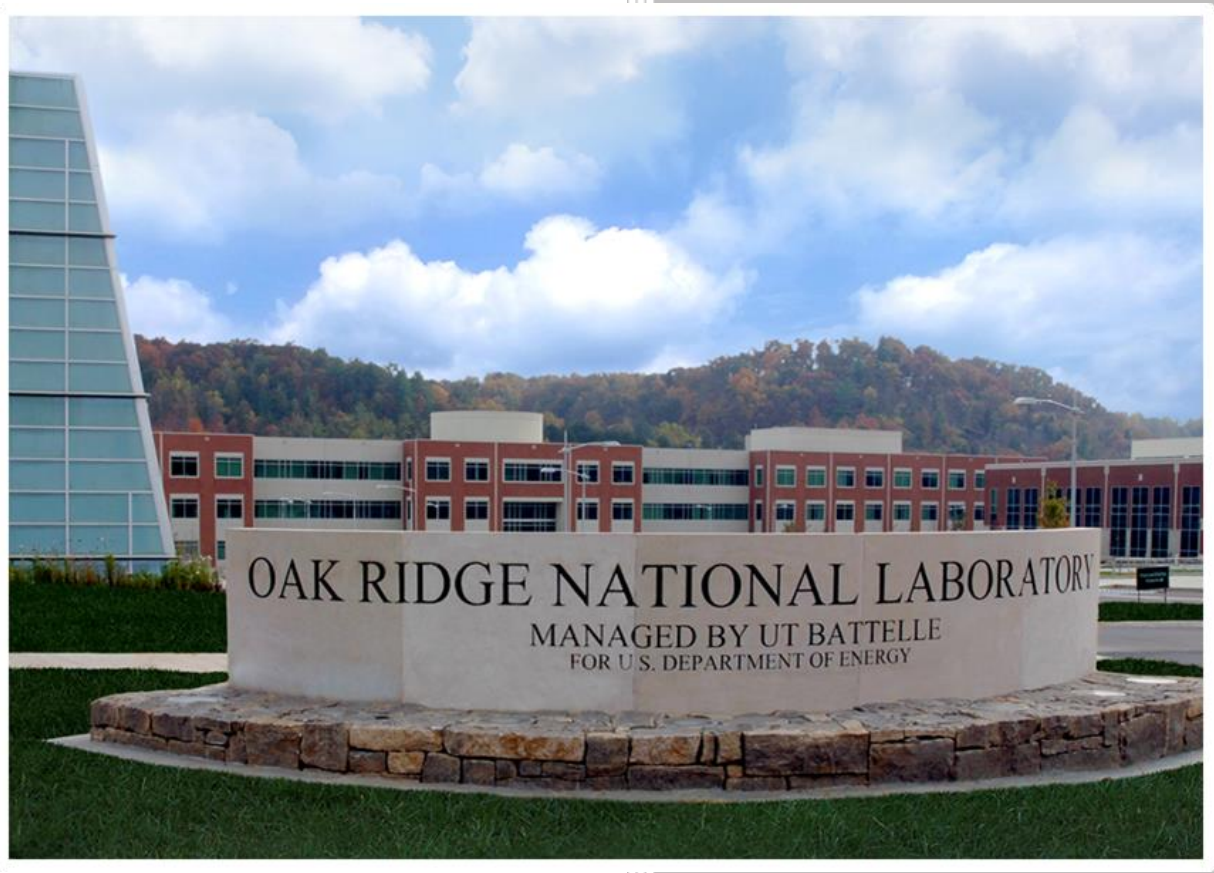

Approved for public release. Distribution is unlimited.

Susan M. Schoenung Rebecca A. Efroymson Matthew $\mathrm{H}$. Langholtz

April 7, 2019 


\title{
DOCUMENT AVAILABILITY
}

Reports produced after January 1, 1996, are generally available free via US Department of Energy (DOE) SciTech Connect.

Website www.osti.gov

Reports produced before January 1, 1996, may be purchased by members of the public from the following source:

\author{
National Technical Information Service \\ 5285 Port Royal Road \\ Springfield, VA 22161 \\ Telephone 703-605-6000 (1-800-553-6847) \\ TDD 703-487-4639 \\ Fax 703-605-6900 \\ E-mail info@ntis.gov \\ Website http://classic.ntis.gov/
}

Reports are available to DOE employees, DOE contractors, Energy Technology Data Exchange representatives, and International Nuclear Information System representatives from the following source:

Office of Scientific and Technical Information

PO Box 62

Oak Ridge, TN 37831

Telephone 865-576-8401

Fax 865-576-5728

E-mail reports@osti.gov

Website http://www.osti.gov/contact.html

This report was prepared as an account of work sponsored by an agency of the United States Government. Neither the United States Government nor any agency thereof, nor any of their employees, makes any warranty, express or implied, or assumes any legal liability or responsibility for the accuracy, completeness, or usefulness of any information, apparatus, product, or process disclosed, or represents that its use would not infringe privately owned rights. Reference herein to any specific commercial product, process, or service by trade name, trademark, manufacturer, or otherwise, does not necessarily constitute or imply its endorsement, recommendation, or favoring by the United States Government or any agency thereof. The views and opinions of authors expressed herein do not necessarily state or reflect those of the United States Government or any agency thereof. 
Environmental Sciences Division

\title{
CONSIDERATIONS FOR THE DESIGN OF A GAS TRANSPORT SYSTEM FOR CO-LOCATION OF MICROALGAE CULTIVATION WITH $\mathrm{CO}_{2}$ SOURCES
}

\author{
Susan M. Schoenung ${ }^{1}$ \\ Rebecca A. Efroymson ${ }^{2}$ \\ Matthew H. Langholtz ${ }^{2}$ \\ ${ }^{1}$ Longitude 122 West, Inc. \\ ${ }^{2}$ Oak Ridge National Laboratory
}

Date Published: April 2019

\author{
Prepared by \\ OAK RIDGE NATIONAL LABORATORY \\ Oak Ridge, TN 37831-6283 \\ managed by \\ UT-BATTELLE, LLC \\ for the \\ US DEPARTMENT OF ENERGY \\ under contract DE-AC05-00OR22725
}





\section{CONTENTS}

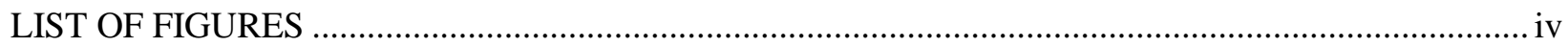

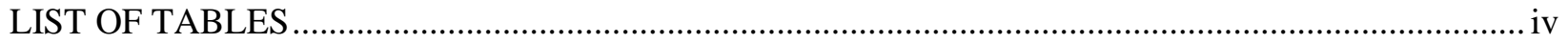

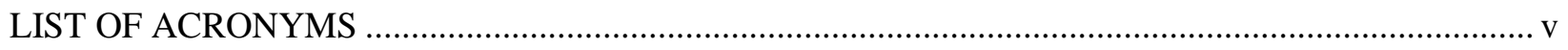

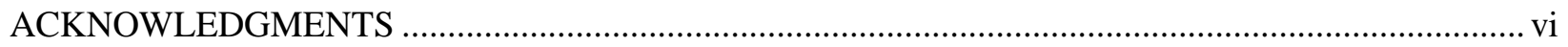

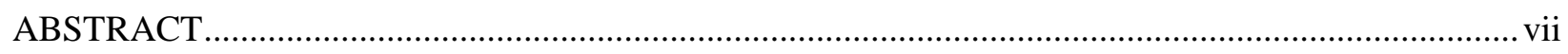

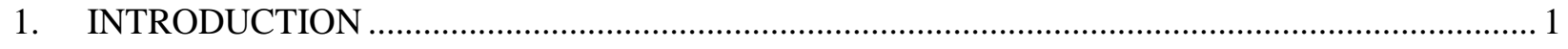

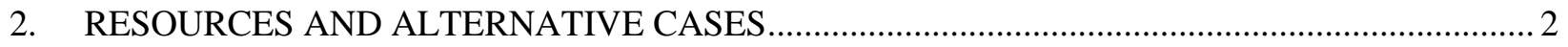

3. ENGINEERING APPROACH AND TRADE-OFF ANALYSIS ............................................. 3

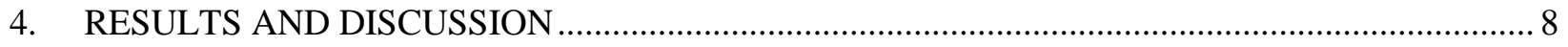

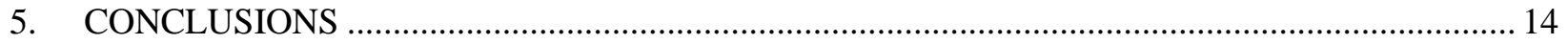

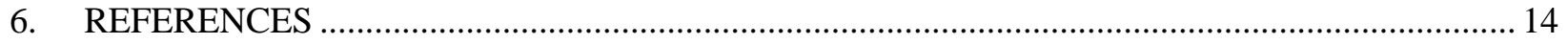




\section{LIST OF FIGURES}

Figure 1. Illustration of co-location strategy to use $\mathrm{CO}_{2}$ emissions from a power or process plant.

Figure 2. Costs of PVC and steel pipeline based on Peters, et al. [28], and updated to 2014 dollars

Figure 3. Example of cost trade-off of capital components and electricity cost as functions of pipe diameter for the base-case algae cultivation assumptions with the $\mathrm{CO}_{2}$ source (coal power plant) co-located $8 \mathrm{~km}$ from the ponds.

Figure 4. Example of trade-off in annual cost between selecting a pipe diameter to minimize capital cost or to minimize electricity cost for a case in which a coal power plant was the $\mathrm{CO}_{2}$ source for the 405-ha set of open algae ponds, and high algae productivity was assumed.

Figure 5. Method for determining break-even transport distance of waste gas from the source to the algae production facility

Figure 6. Cost-effective $\mathrm{CO}_{2}$ transport distances (relative to $\$ 44 /$ tonne $\mathrm{CO}_{2}$ ) for the resources considered under base-case conditions.

Figure 7. Cost-effective $\mathrm{CO}_{2}$ transport distances (relative to $\$ 44 /$ tonne $\mathrm{CO}_{2}$ ) for the resources considered under base-case, higher-productivity, smaller-facility, and 24-hr- $\mathrm{CO}_{2}$-capture conditions.....

Figure 8. Comparison of costs for 12-hour base-case $\mathrm{CO}_{2}$ transport with the 24-hr $\mathrm{CO}_{2}$-capture case for a coal power plant at an $8-\mathrm{km}$ distance.

\section{LIST OF TABLES}

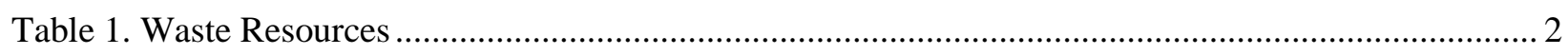

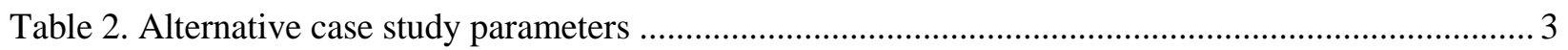

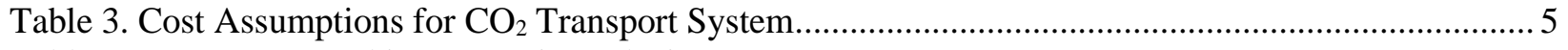

Table 4. Parameters used in economic analysis ................................................................................ 7

Table 5. Cost-effective $\mathrm{CO}_{2}$ transport distances for the base case and cases with alternative algae cultivation parameters. 


\section{LIST OF ACRONYMS}

DOE U.S. Department of Energy

EGU electricity-generating unit

NG natural gas

O\&M operations and maintenance

USEPA U.S. Environmental Protection Agency 


\section{ACKNOWLEDGMENTS}

We thank André Coleman and Mark Wigmosta for algae biomass modeling linked to the engineering analysis described here. André Coleman, as well as Shahab Sokhansanj, Tim Theiss, and an anonymous reviewer, provided review comments on earlier versions of this report. This research was supported by the U.S. Department of Energy (DOE) under the Bioenergy Technologies Office. Oak Ridge National Laboratory is managed by UT-Battelle, LLC, for DOE under contract DE-AC05-00OR22725. Special thanks are due David Hazlebeck for discussion of the 24-hour supply alternative, and Blair Larson for information on suitable gas compressors. We thank BCS, Inc., for the final drawing of Figure 1. This manuscript has been authored by UT-Battelle, LLC under Contract No. DE-AC05-00OR22725 with the US Department of Energy. The United States Government retains and the publisher, by accepting the article for publication, acknowledges that the United States Government retains a non-exclusive, paid-up, irrevocable, worldwide license to publish or reproduce the published form of this manuscript, or allow others to do so, for United States Government purposes. The Department of Energy will provide public access to these results of federally sponsored research in accordance with the DOE Public Access Plan (http://energy.gov/downloads/doe-public-access-plan). The views and opinions of the authors expressed herein do not necessarily state or reflect those of the United States Government or any agency thereof. Neither the United States Government nor any agency thereof, nor any of their employees, makes any warranty, expressed or implied, or assumes any legal liability or responsibility for the accuracy, completeness, or usefulness of any information, apparatus, product, or process disclosed, or represents that its use would not infringe privately owned rights. 


\begin{abstract}
Co-locating microalgae cultivation facilities with sources of waste $\mathrm{CO}_{2}$ may present opportunities for cost savings that could benefit the algal biomass industry and industries or utilities that have incentives to manage carbon emissions. However, the cost savings have not been quantified. We compare the cost of utilizing $\mathrm{CO}_{2}$ from flue gas transported to 405 -ha, base-case, open-pond microalgae facilities to the commercial purchase price of $\mathrm{CO}_{2}$. Sources of $\mathrm{CO}_{2}$ include coal- and natural gas-fired power plants and ethanol, ammonia, and cement production plants in the United States. The transport of $\mathrm{CO}_{2}$-containing gases to the microalgae cultivation facility requires infrastructure and electricity. This engineering analysis explores the parameters that affect the infrastructure and transport distance over which emitted flue gases can be cost-effectively transported to microalgae cultivation facilities, compared to the cost of commercially purchased $\mathrm{CO}_{2}$ (i.e., the break-even distance). Parameters that are varied include size of facility pond area, productivity, and daily duration of waste $\mathrm{CO}_{2}$ emissions that are transported to algae. Under our assumptions and under all cases in this study, cost savings can be achieved by co-locating microalgae facilities near waste $\mathrm{CO}_{2}$ sources. The break-even distance, which is estimated here to range from under 2 to $80 \mathrm{~km}$, depends primarily on the concentration of $\mathrm{CO}_{2}$ in flue gas, algae productivity, facility size, and pipeline system design considerations. Greater break-even distances are simulated if electricity cost is minimized, rather than if capital cost is minimized.
\end{abstract}




\section{INTRODUCTION}

The U.S. Department of Energy's (DOE) 2016 Billion-Ton Report: Advancing Domestic Resources for a Thriving Bioeconomy [1] presents microalgae as a viable source of biomass for biofuel in the United States, but at substantially higher prices than terrestrial biomass, due in part to different nutrient, infrastructure (e.g., pond liners), and energy requirements (e.g., paddlewheels), compared to inputs for agriculture. Strategies are needed to reduce operational costs of microalgae biomass cultivation used for biofuels and bioproducts. Carbon is a required nutrient for microalgae growth, and the purchase of compressed $\mathrm{CO}_{2}$ to allow high-productivity microalgae cultivation can contribute up to $40 \%$ of the raw material cost [2] or cost \$101/tonne algae biomass (ash-free dry weight) [3].

Co-location strategies that pair a cultivation system, such as an engineered open pond, with an existing industrial facility allow the emitter to potentially reduce waste management costs, while providing reduced-cost gas delivery to the microalgae producer, as well as the potential for waste heat utilization in cooler climates. Potential advantages of co-locating microalgae biomass cultivation facilities with point sources of waste $\mathrm{CO}_{2}$ have been demonstrated at pilot plants and at commercial scale [4-9, 2 4]. Some variables affecting greenhouse-gas-emissions life-cycle analysis from utilities co-located with algae facilities, such as facility size and $\mathrm{CO}_{2}$ concentration in waste gas, have been explored [10]. However, the cost of transporting bulk flue gas in quantities sufficient to support high-productivity, commercial-scale algae development, as well as cost-effective transport distances, has not been estimated and published in the past two decades (see the 4.8-km assumption for flue gas in [11]) for any algae cultivation system. Venteris et al. [12] and Quinn and Davis [13] note that costs associated with delivering flue gas and costeffective transport distances are needed for techno-economic analyses and resource assessments for microalgae biofuel production. Beal et al. [14] assert that the "proximity and quality of the carbon source is one of the most important parameters for algal biofuel production." In techno-economic analyses, the uncertainty regarding the cost-effective transport distance for $\mathrm{CO}_{2}$-containing gases has been handled by assuming a baseline, lower bound and upper bound value, as in the distances of $4.8 \mathrm{~km}, 1.6 \mathrm{~km}$, and 16 $\mathrm{km}$, respectively, used in Quinn et al. [15] to represent distances for transport of co-located waste $\mathrm{CO}_{2}$ emitted at a variety of concentrations. Lundquist et al. [16] considered algae co-location distances of 1.6, 3.2 , and $4.8 \mathrm{~km}$ from power plants.

The U.S. emits more than 3.0 billion tonnes of $\mathrm{CO}_{2}$ per year from point sources that could potentially be used in algal biomass cultivation [17], over 2 billion tonnes of which is from the electric power sector [18]. The vast majority of this waste resource is not used, though $\mathrm{CO}_{2}$-enhanced oil recovery utilizes more than 50 million tonnes of $\mathrm{CO}_{2}$ per year.

The primary objective of this study is to explore the design considerations for sizing and costing a system to transport waste, $\mathrm{CO}_{2}$-containing gas over some distance to the algae cultivation facility. The overall concept for co-location is shown in Figure 1. Feasible $\mathrm{CO}_{2}$ transport distance results for power plants and ethanol production plants were used to estimate U.S. national potential microalgae resource availability in the 2016 Billion-Ton Report [1], and this analysis builds on the engineering cost simulations for that work by adding $\mathrm{CO}_{2}$ sources, alternative project cases, installation costs, and additional infrastructure costs. 


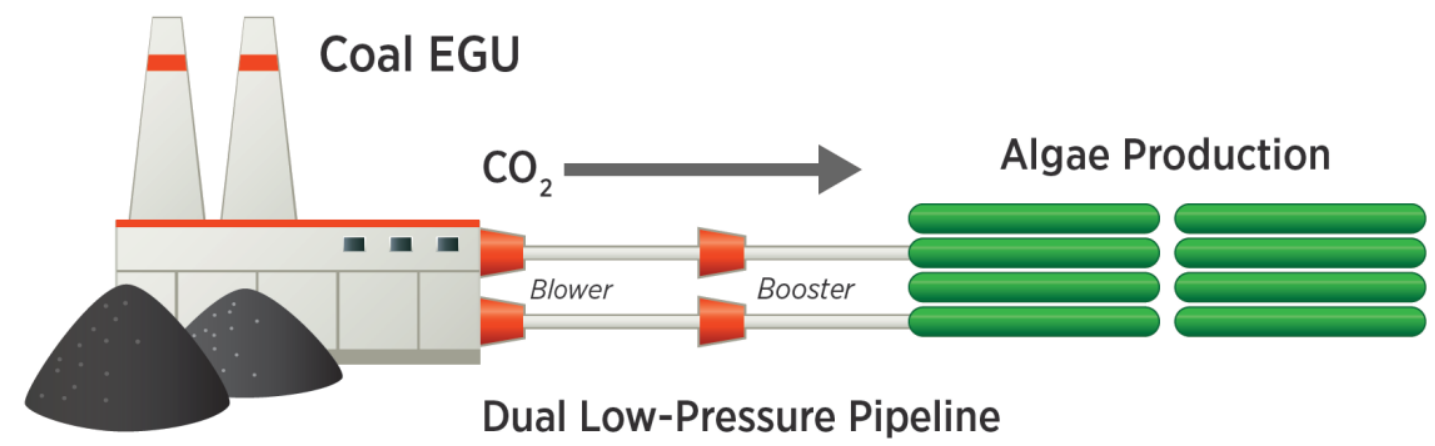

Figure 1. Illustration of co-location strategy to use $\mathrm{CO}_{2}$ emissions from a power or process plant. In this figure, the source is a coal-fired power plant (EGU=electricity-generating unit). The number and size of blowers and pipelines vary with gas volume.

\section{RESOURCES AND ALTERNATIVE CASES}

The co-location strategies focus on major classes of emitters of $\mathrm{CO}_{2}$ with different concentrations of $\mathrm{CO}_{2}$ in the waste gas stream, i.e., coal (14\%) and natural gas-fired power plants (5\%) [19], ethanol production plants (99\%) [20], ammonia production plants (97\%) [21] and cement manufacturing plants (24\%) [22]. The emissions from the cement kiln $\left(47 \% \mathrm{CO}_{2}\right)$ were analyzed, as well as the combined emissions from the cement plant, which mixes flue gas from the kiln and heat plant together. These sources represent a large range of volumetric concentrations of $\mathrm{CO}_{2}$ in emitted gas, as indicated in Table 1 , leading to a large range of estimated pipe sizes and resulting transport costs.

Table 1. Waste Resources

\begin{tabular}{|l|c|}
\hline \multicolumn{1}{|c|}{ Waste Resource } & $\mathbf{C O}_{2}$ Concentration, \% \\
\hline Ethanol plant & 99 \\
\hline Ammonia plant & 97 \\
\hline Cement kiln (part of cement plant) & 47 \\
\hline Cement plant & 24 \\
\hline Coal-fired power plant & 14 \\
\hline Natural gas-fired power plant & 5 \\
\hline
\end{tabular}

The following base case parameters were established: a microalgae cultivation facility with 405 ha (1000 acres) of open ponds operated at $30-\mathrm{cm}$ depth. The base case assumes a moderate annual average biomass productivity of $13.2 \mathrm{~g} \mathrm{~m}^{-2} \mathrm{~d}^{-1}$, which corresponds to national mean annual average productivities assumed in previous studies to be achievable under currently available technologies using available strains [23, 1]. $\mathrm{A} \mathrm{CO}_{2}$ uptake value of $82 \%$ is used, as assumed in other modeling studies [12, 1]. In addition to the base case, three alternative cases aimed primarily at understanding scaling issues are compared with the base case. With six $\mathrm{CO}_{2}$ resources and the base case with three cases with altered cultivation parameters, a total of 24 cases of $\mathrm{CO}_{2}$ transport to algae facilities are evaluated in this study.

The base case, a single 405-ha (1000-acre) microalgae cultivation facility, calls for 107 tonnes of $\mathrm{CO}_{2}$ per day on average, or over 36,400 tonnes per year. This is a fraction of the emissions from a typical ethanol production plant, which releases over 227,000 tonnes of $\mathrm{CO}_{2}$ per year, or a coal-fired power plant, which releases 1.36 to 18 million tonnes of $\mathrm{CO}_{2}$ per year [24]. Thus, scaling to larger cultivation facilities would be possible with these resources. 
Three alternative cases are modeled (Table 2). A smaller, 202-ha (500-acre) facility is considered because contiguous parcels of 405 ha may not be located near some of the $\mathrm{CO}_{2}$ sources. A future higher annual average productivity of $25 \mathrm{~g} \mathrm{~m}^{-2} \mathrm{~d}^{-1}$ is an additional case, consistent with a targeted productivity rate used in a recent U.S. microalgae pond design study and in the 2016 Billion Ton Report $[3,1]$. The base case and these two alternative cases assume $\mathrm{CO}_{2}$ is captured for an average of $12 \mathrm{hr} /$ day while the ponds are sunlit and productive. Costs for an alternative case that assumes an innovative technology allowing 24hour capture and storage of $\mathrm{CO}_{2}$ are also estimated. In that case the microalgae use the $\mathrm{CO}_{2}$ emitted during both day and night for growth in daylight. Based on a concept used by Global Algae Innovations [25], the $\mathrm{CO}_{2}$ is removed from the waste gas using a packed-bed wet scrubber (specially designed packing medium wetted with liquid through which the gas flows) and storage pool for the dissolved $\mathrm{CO}_{2}$, Water with dissolved $\mathrm{CO}_{2}$ is fed directly to the algae pond when needed. Line-packing, whereby $\mathrm{CO}_{2}$ is stored within the pipeline itself by closing valves and increasing pressure at select locations [26], is not considered in this study. The four alternative cultivation cases are summarized in Table 2.

Table 2. Alternative case study parameters

\begin{tabular}{|l|c|c|c|c|}
\hline \multicolumn{1}{|c|}{ Case } & $\begin{array}{c}\text { Productivity g } \\
\mathbf{m}^{-2} \mathbf{d}^{-\mathbf{1}}\end{array}$ & $\begin{array}{c}\text { Algae facility size, } \\
\text { hectares (acres) }\end{array}$ & $\begin{array}{c}\text { Average hours of waste } \\
\text { gas capture/day }\end{array}$ & $\begin{array}{c}\text { Required CO} \mathbf{2}, \\
\text { tonnes per year* }\end{array}$ \\
\hline Base case & 13.2 & $405(1000)$ & 12 & 43,343 \\
\hline Smaller farm & 13.2 & $202(500)$ & 12 & 21,739 \\
\hline $\begin{array}{l}\text { Higher } \\
\text { productivity }\end{array}$ & 25 & $405(1000)$ & 12 & 82,345 \\
\hline $\begin{array}{l}\text { 24-hour } \mathrm{CO}_{2} \\
\text { capture }\end{array}$ & 13.2 & $405(1000)$ & 24 & 43,343 \\
\hline
\end{tabular}

* Based on uptake rate of $82 \%$, as assumed in [12] and [1]

\section{ENGINEERING APPROACH AND TRADE-OFF ANALYSIS}

The engineering approach involves sizing and costing the gas transport system, which consists of pipelines and gas blowers (i.e., devices for moving volumes of gas with a moderate increase of pressure). Figure 1 shows a representative depiction of the system design. Flue gas is captured at the plant and transported as relatively low-pressure gas $(144.8 \mathrm{kPa})$ through a pipeline to the microalgae cultivation facility. Depending on the distance and flowrate, either a single pipe or a series of pipes with one or more blower stations is sufficient to move the gas to the cultivation site. The engineering analysis is used to determine the size and costs of the pipe, blowers and energy requirements for each of the 24 cases. The governing equation for gas flow is as follows (SPE 2015)[27])

$$
P_{1}^{2}-P_{2}^{2}=0.205\left[\left(S Q_{g}^{2} Z T f L\right) / d^{5}\right]
$$

Where

$\begin{array}{lll}P_{1} & = & \text { upstream pressure, } \mathrm{kPa}, \\ P_{2} & = & \text { downstream pressure, } \mathrm{kPa}, \\ S & = & \text { specific gravity of gas, dimensionless } \\ Q_{g} & = & \text { gas flow rate, } \mathrm{Sm}^{3} / \mathrm{hr}, \\ Z & = & \text { compressibility factor for gas, dimensionless, } \\ T & = & \text { flowing temperature, } \\ & { }^{\circ} \mathrm{K} \\ f & = & \text { Moody friction factor, dimensionless, } \\ d & = & \text { pipe internal diameter, } \mathrm{cm}, \\ L & = & \text { length, } \mathrm{m}\end{array}$

The Moody friction factor is a function of Reynolds number. 
For the case of a series of blowers, the upstream pressure is $144.8 \mathrm{kPa}(21 \mathrm{psia})$ and the pressure drop between blowers is a maximum of $13.8 \mathrm{kPa}(2 \mathrm{psig})$. Properties for either carbon dioxide or gas mixtures are used. The flow is fully turbulent.

The required gas flowrate, $\mathrm{Q}$, is determined by the assumed productivity of the microalgae, pond area, and the concentration of $\mathrm{CO}_{2}$ in the flue gas, such that adequate $\mathrm{CO}_{2}$ is available for the microalgae during the growing period in each day. As seen in Equation 1, the pipeline diameter, $d$, is an important variable in determining the pressure drop along the pipe, and this dominates the decision for selecting design parameters to reduce the overall cost of the transport system for a given distance from the emission source. There is a trade-off between the cost of pipe, which increases nonlinearly with diameter, and the cost of blowers, the number of which depends on the pressure drop between stations. The costing analysis computes the capital cost of pipeline and blowers plus the operating cost for electricity. For the 24-hour $\mathrm{CO}_{2}$ capture case, a scrubber and pool are added in sequence following the pipeline and immediately before the algae pond. The gas distribution system within the pond is not costed in this study and would vary for different cases, such as for facilities of different sizes or locations with different productivities. The capital cost is computed as in Equation 2.

$$
\mathrm{C}_{\mathrm{cap}}=\mathrm{C}_{\mathrm{p}} \mathrm{xL}+\mathrm{C}_{\mathrm{b}}+\mathrm{C}_{\mathrm{sp}}
$$

Where:

$$
\begin{aligned}
& \mathrm{C}_{\mathrm{cap}}=\text { Capital cost, } \$ \\
& \left.\mathrm{C}_{\mathrm{p}}=\text { Cost of pipe, } \$ / \mathrm{m} \text { (See Figure } 2\right) \\
& \mathrm{L}=\text { Pipe length, } \mathrm{km} \\
& \mathrm{C}_{\mathrm{b}}=\text { Cost of blower(s), } \$ \\
& \mathrm{C}_{\mathrm{sp}}=\text { Cost of scrubber and pool, } \$ \text { (optional) }
\end{aligned}
$$

Table 3 indicates the cost assumptions used in this study. The pipe cost (per linear dimension) is estimated from an engineering handbook [28] and updated to 2014 dollars. Because PVC is less expensive than steel, as shown in Figure 2, the former material is used in the pipeline design wherever possible. Furthermore, smaller parallel pipes are selected over fewer larger steel pipes for the same reason.
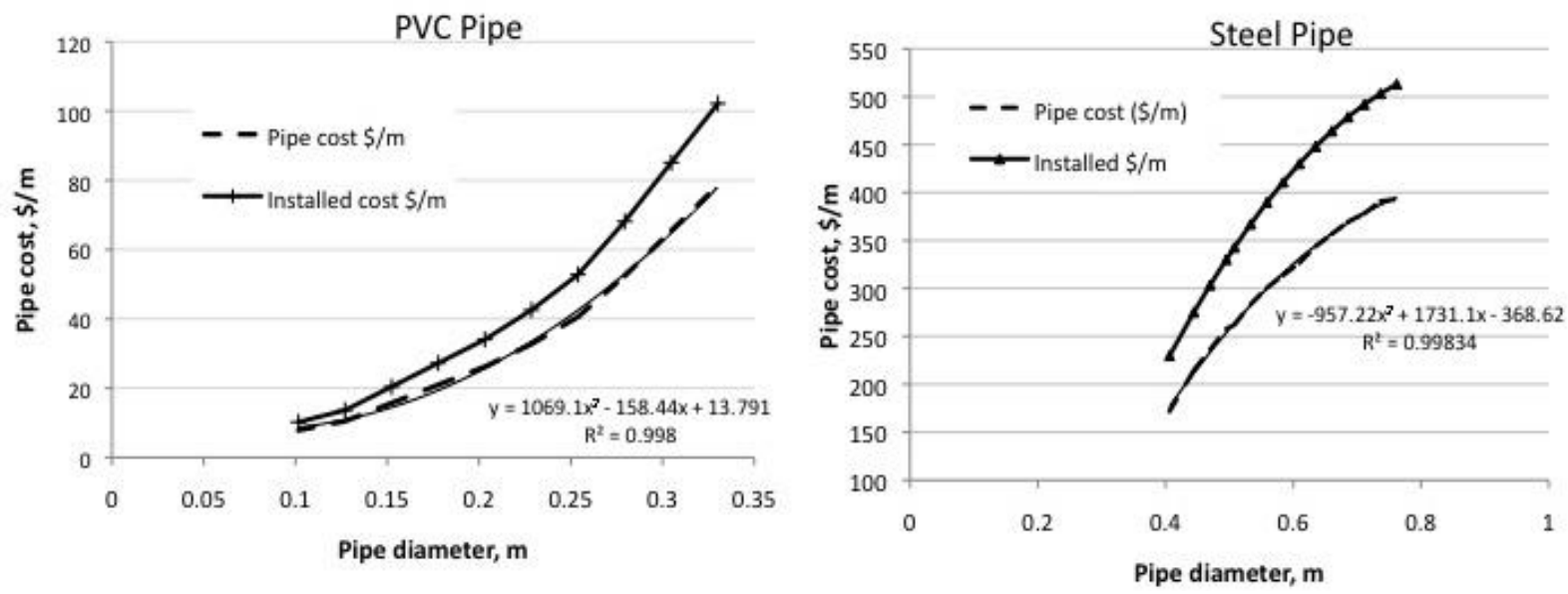

Figure 2. Costs of PVC and steel pipeline based on Peters, et al. [28], and updated to 2014 dollars. Installation factor based on Janna [29]. 
The cost of the blower system is estimated from discussions with industry, and the electric power requirement for the blower is estimated from industrial literature [30]. Similar to the approach used in previous techno-economic analyses of algae production [31-33], an installation factor is applied to determine the total capital investment. To estimate the installation factor for the pipeline in this study, the material cost is compared to the installed cost of steel pipeline in Janna [29]. Based on this comparison, the installation factor is set to 1.3 and applied to the capital costs in this study. Valve and fitting estimates are derived from Peters et al. [28]. Earth works for the pipeline are not included in the cost, nor are sensors or potential needs for $\mathrm{SO}_{\mathrm{x}}$ control or $\mathrm{NO}_{\mathrm{x}}$ control for power plant flue gas [9]. The capital and operating cost assumptions for the 24-hr capture and storage case are derived from U.S. Environmental Protection Agency (USEPA) literature [34] and verified in discussion with industry [25]. The fixed operations and maintenance $(\mathrm{O} \& \mathrm{M})$ cost of $4 \%$ of capital per year is based on engineering experience for power plants [35]. In addition, the approximate cost of a small quantity of buffer storage is included to hold 10 minutes of the daily flow of gas. The purpose of the buffer storage is to respond to dynamics in the flow as the gas reaches the pond, either from the source or from the gas entering into the pond distribution system.

To minimize capital cost, a trade-off is made between the cost of selected blower equipment and the cost of pipeline. An example of this trade-off is shown in Figure 3, where pipe cost dominates for larger pipes, but blower cost increases with smaller pipes. The latter is due to greater pressure drop along the smaller pipes, thus requiring more blower stations. Figure 3 also shows the blower-related electricity cost, which scales with the number of blowers.

Table 3. Cost Assumptions for $\mathrm{CO}_{2}$ Transport System

\begin{tabular}{|c|c|c|}
\hline Item & Cost & Notes \\
\hline & Capital Cost & \\
\hline PVC Pipe & See Figure 2. & Used for pipe diameters up to $38 \mathrm{~cm}$ \\
\hline Steel Pipe & See Figure 2. & Used for pipe diameters from 38 to $76 \mathrm{~cm}$ \\
\hline Blower & $\begin{array}{l}\text { Scales from } \$ 25,000 \text { for } 5340 \\
\mathrm{Nm}^{3} / \mathrm{hr}\end{array}$ & $\begin{array}{l}\left.\text { Atlas Copco model ZM88 (890- } 8010 \mathrm{Nm}^{3} / \mathrm{hr}\right) \\
\max \mathrm{P}=144.8 \mathrm{kPa}[30]\end{array}$ \\
\hline Valves / fittings & $\begin{array}{l}\text { Ranges from } \$ 1310 \text { to } \$ 13,100 \text { per } \\
\text { each depending on pipe size } \\
{[28]}\end{array}$ & One valve system for each blower \\
\hline \multirow[t]{2}{*}{ Scrubber and pool } & $\$ 56.2 \$ / \mathrm{Nm}^{3} / \mathrm{hr}$ & $\begin{array}{l}\text { Based on discussion with industry, and } \\
\text { comparable to USEPA values [34] }\end{array}$ \\
\hline & O\&M Costs & \\
\hline Fixed O\&M (annual) & $4 \%$ of total capital cost & $\begin{array}{l}\text { Consistent with power plant engineering } \\
\text { economics [35] }\end{array}$ \\
\hline Electricity & 8 cents/kWh & Consistent with other DOE studies [35] \\
\hline \multirow[t]{2}{*}{$\begin{array}{l}\text { Scrubber consumables } \\
\text { (annual) }\end{array}$} & $11.2 \$ / \mathrm{Nm}^{3} / \mathrm{hr}$ & $\begin{array}{l}\text { Based on [34] and consistent with industry } \\
\text { experience [25] }\end{array}$ \\
\hline & Installation Costs & \\
\hline Installation factor & 1.3 & Factor by which capital costs are multiplied [29] \\
\hline
\end{tabular}




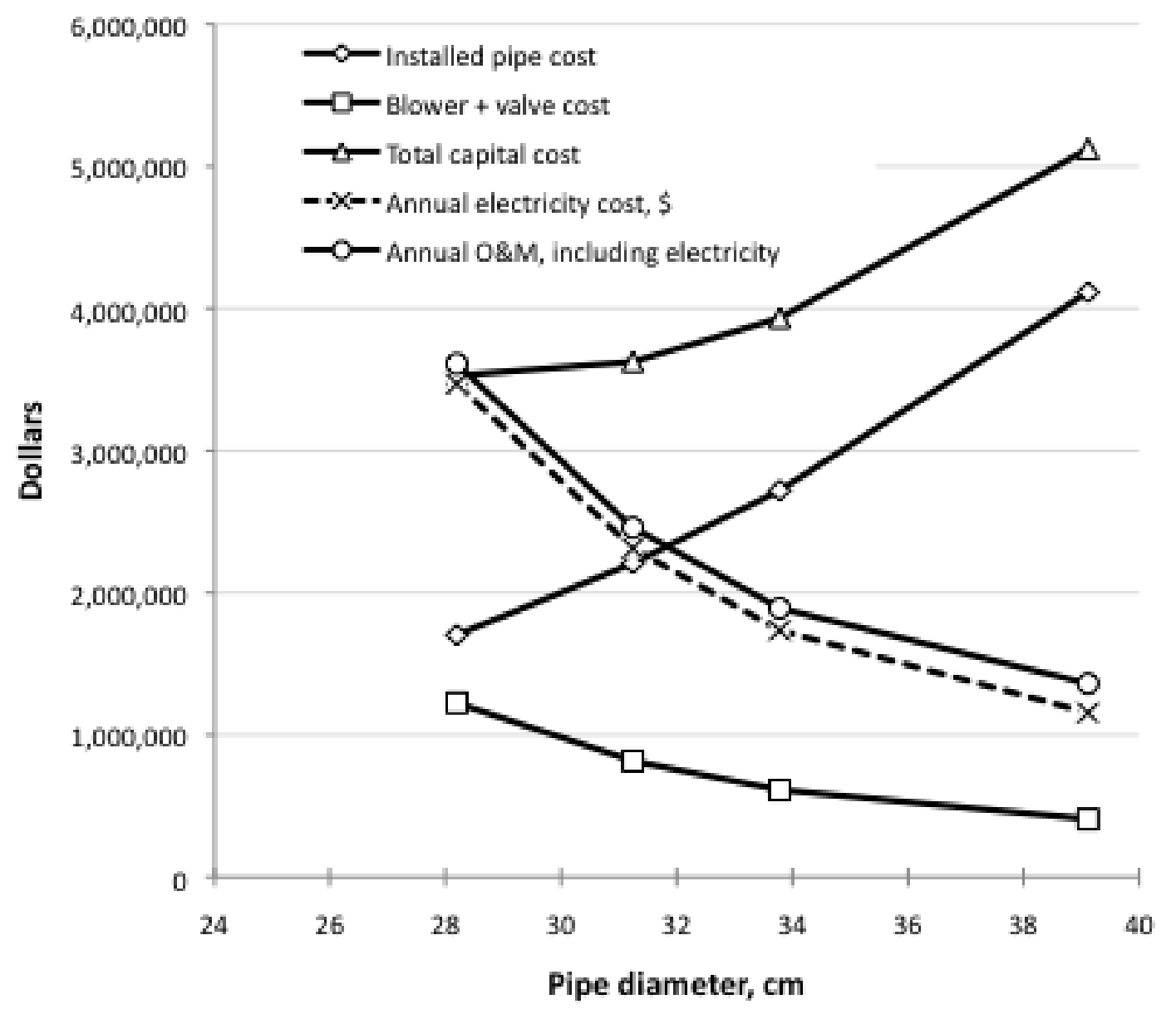

Figure 3. Example of cost trade-off of capital components and electricity cost as functions of pipe diameter for the base-case algae cultivation assumptions with the $\mathrm{CO}_{2}$ source (coal power plant) co-located $8 \mathrm{~km}$ from the ponds. This configuration uses 3 pipes in parallel. O\&M is operation and maintenance.

The benefit of the 24-hr $\mathrm{CO}_{2}$ capture approach with respect to gas transport is a smaller, less expensive pipeline and blower system, because the required amount of gas is carried over a longer period of time. This savings is offset, however, by the additional capital and operating costs of the packed-bed wet scrubber and storage pool for dissolved $\mathrm{CO}_{2}$, costs which are considered for the 24-hr $\mathrm{CO}_{2}$-capture cases.

The life-cycle cost of the gas transport system is calculated so that a further trade-off can be made between capital cost and operating (e.g., electricity) cost. The economic parameters for the life-cycle cost are listed in Table 4. The annual cost is summed as in Equation 3. An example of the annualized value of capital cost plus electricity and O\&M is shown in Figure 4. Note that this study did not estimate greenhouse gas emissions through a life-cycle analysis; however, selecting a system that reduces the electricity usage will also reduce emissions.

$$
\begin{aligned}
\text { Annual cost }= & \text { Annualized cost of capital equipment and installation }+ \\
& \text { annual cost of electricity }+ \text { annual O\&M }
\end{aligned}
$$


Table 4. Parameters used in economic analysis

\begin{tabular}{|l|l|}
\hline \multicolumn{1}{|c|}{ Parameter } & \multicolumn{1}{|c|}{ Value } \\
\hline Purchase price of $\mathrm{CO}_{2}$ & $\$ 44 /$ tonne \\
\hline Price of electricity & $\$ 0.08 / \mathrm{kWh}$ \\
\hline Life time for annual calculation & 30 years \\
\hline Interest rate & $10 \%$ \\
\hline Average daily duration of $\mathrm{CO}_{2}$ capture & $12 \mathrm{hr} /$ day (base case) \\
\hline
\end{tabular}

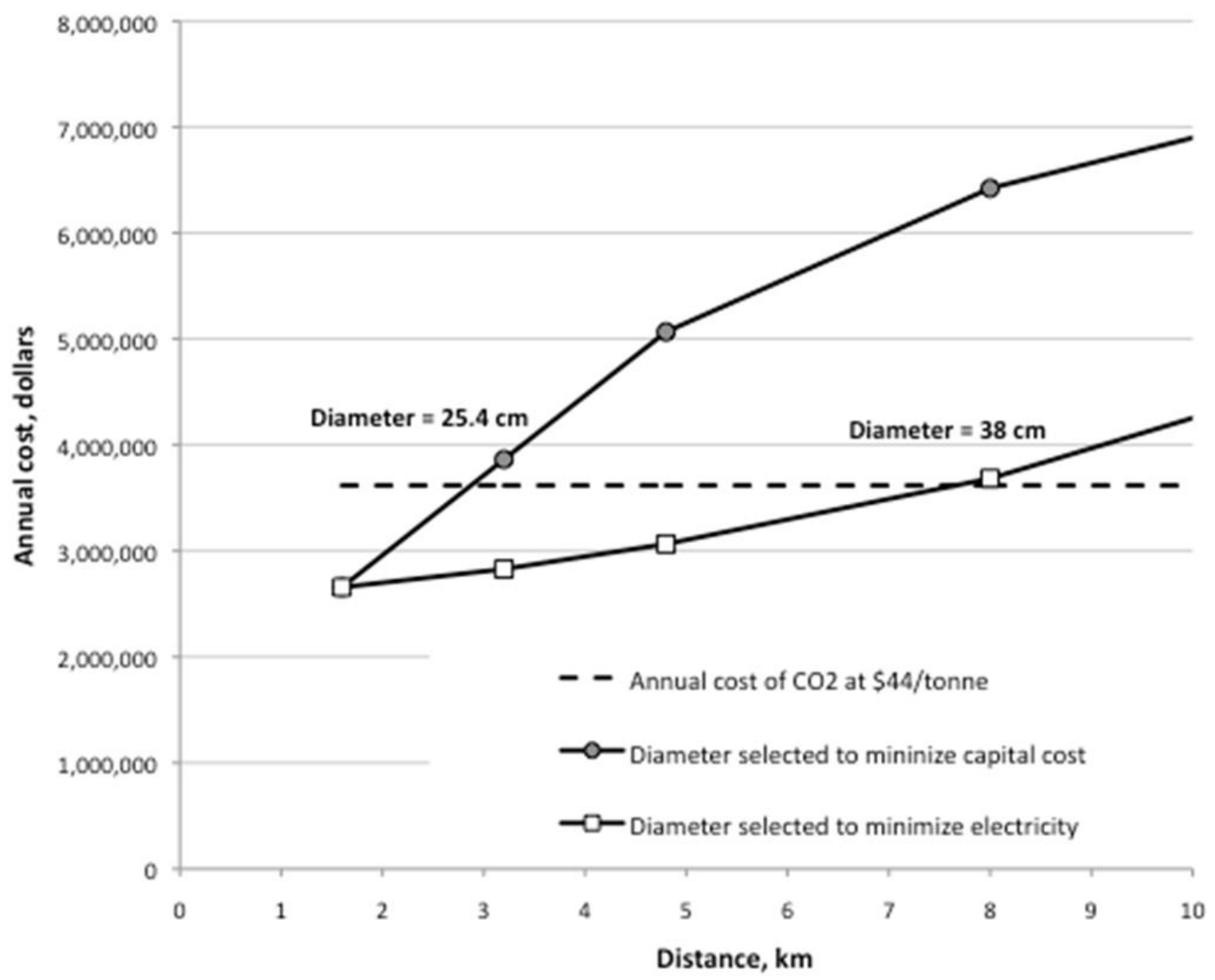

Figure 4. Example of trade-off in annual cost between selecting a pipe diameter to minimize capital cost or to minimize electricity cost for a case in which a coal power plant was the $\mathrm{CO}_{2}$ source for the 405-ha set of open algae ponds, and high algae productivity was assumed. For this case, 6 parallel pipes were selected.

The estimated break-even transport distance is determined by comparing the annualized costs of capital plus operations to the cost of purchased $\mathrm{CO}_{2}$. For this study, the commercial purchase price of $\mathrm{CO}_{2}$ was assumed to be $\$ 44 /$ tonne, a cost assumed in other recent studies $[35,36]$. Other assumptions include a 30year life of the transport system, $10 \%$ interest rate on capital, and 8 cents/kWh for electricity [23]. The method for determining the break-even gas transport distance for the coal-fired power plant source is illustrated in Figure 5, where the annualized cost crosses the \$44/tonne line. 


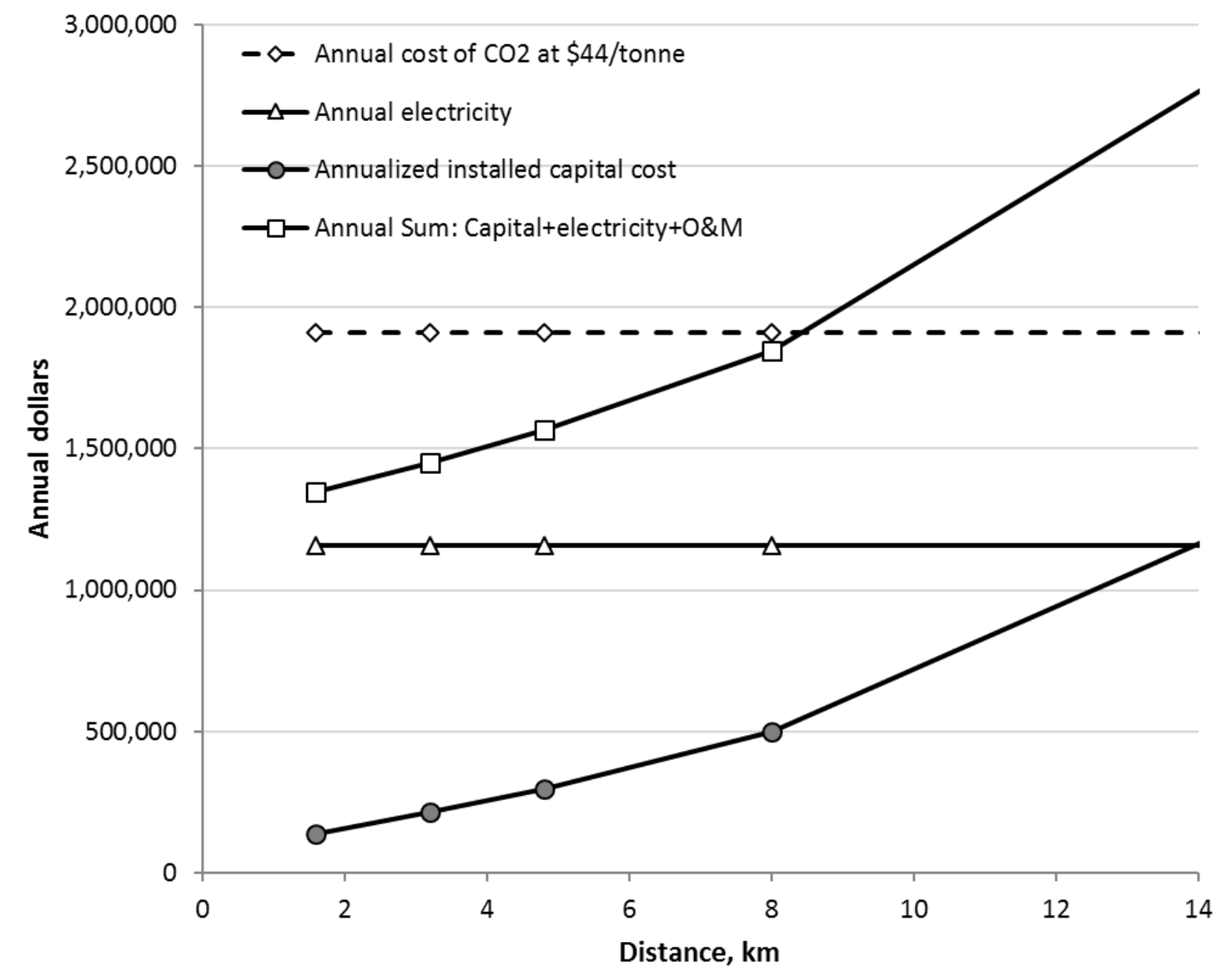

Figure 5. Method for determining break-even transport distance of waste gas from the source to the algae production facility. The break-even distance occurs where the curve of annual cost of capital plus O\&M expenses cross the curve depicting cost of purchased $\mathrm{CO}_{2}$ (at $\$ 44 /$ tonne). This example is for the case of flue gas from a coalfired power plant, including three sets of pipelines with one blower each, to a 405 -ha set of open ponds under base case conditions.

\section{RESULTS AND DISCUSSION}

$\mathrm{CO}_{2}$ is a greenhouse gas that is emitted by various utilities and industries. Existing and incipient commercial enterprises, such as the algal biofuel industry, view waste $\mathrm{CO}_{2}$ as a resource. This study investigated the costs of using waste $\mathrm{CO}_{2}$ transported to algae facilities as a resource for growing biomass, compared to the cost of purchasing the nutrient.

Cost-effective transport distances for $\mathrm{CO}_{2}$-containing waste gases from the six utility and industrial sources under base-case cultivation conditions and assumptions are shown in Figure 6. Beyond these distances, purchased $\mathrm{CO}_{2}$ would be less expensive than the use of waste $\mathrm{CO}_{2}$. The gray bars in the chart indicate the distance at which capital cost for the $\mathrm{CO}_{2}$ transport system is minimized by using smaller pipe at the expense of greater electricity cost. The black bars indicate the distance where electricity costs to transport the required $\mathrm{CO}_{2}$ are minimized by spending more capital on larger pipes. Also shown at the top of the bars on the chart is the concentration of $\mathrm{CO}_{2}$ in the waste gas from the source. For the high $\mathrm{CO}_{2}$ concentration cases (ethanol and ammonia), fairly long cost-effective distances of more than $40 \mathrm{~km}$ are possible, under our assumptions. Clearly, the lower the concentration of $\mathrm{CO}_{2}$, the greater is the gas volume required to produce the algae and the closer the source must be to reduce transport costs. For a 405-ha set of ponds at an 8-km distance from a coal-fired power plant, savings of $\$ 65,000 /$ year over the costs of $\mathrm{CO}_{2}$ purchase are realized under the assumptions described here. For ponds fed by $\mathrm{CO}_{2-}$ 
containing gas from an ethanol production plant at the same distance, the savings is over $\$ 1.5$ million/year.

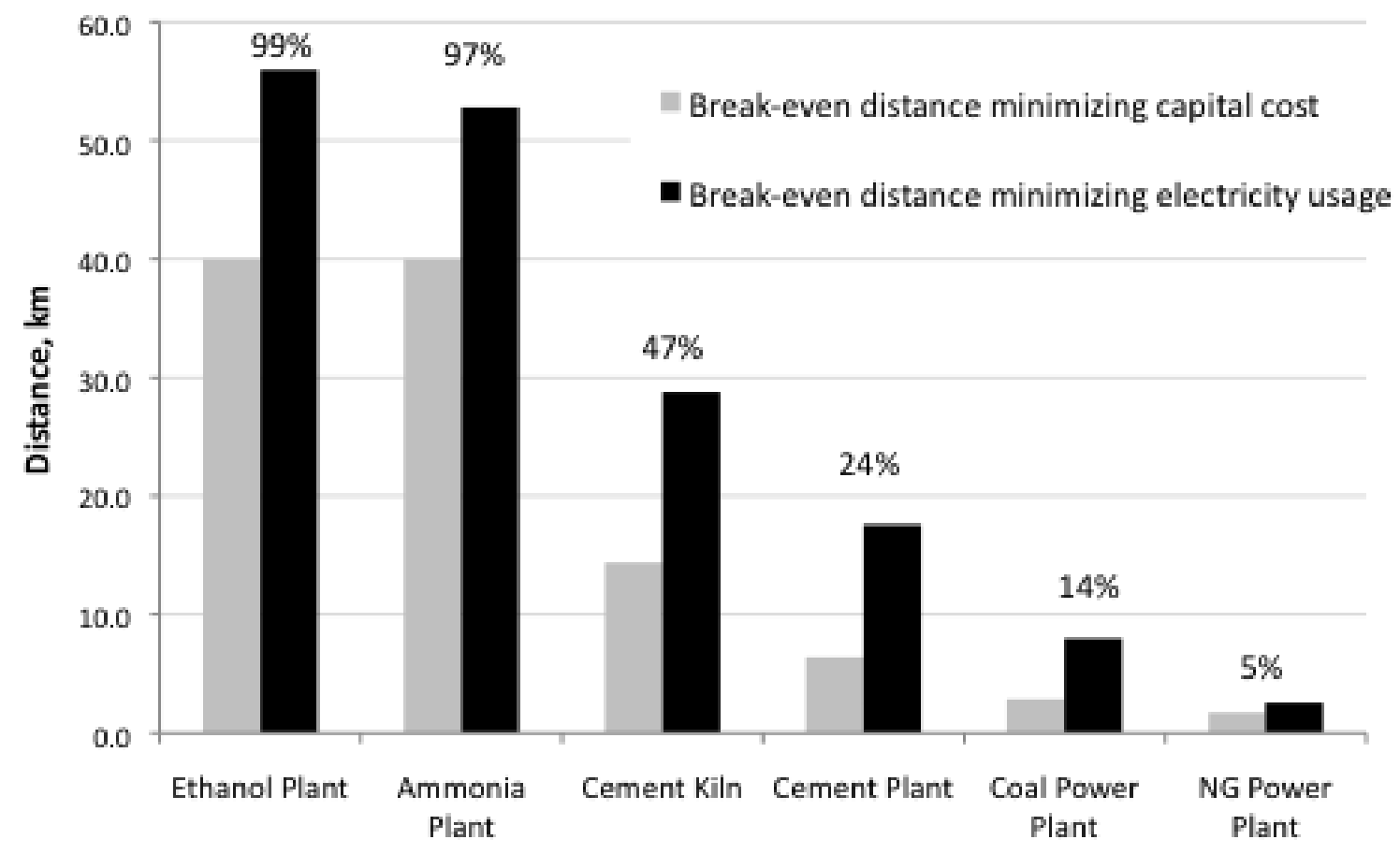

Figure 6. Cost-effective $\mathrm{CO}_{2}$ transport distances (relative to $\$ 44 /$ tonne $\mathrm{CO}_{2}$ ) for the resources considered under base-case conditions. Gray bars depict the break-even distances for the configuration that minimizes capital cost of the transport system to the algae facility at the expense of more electricity, while black bars correspond to configurations that minimize the additional electricity cost for transporting $\mathrm{CO}_{2}$ at the expense of greater capital cost. The percentages above each bar depict the concentration of $\mathrm{CO}_{2}$ in the waste gas. NG is natural gas.

The results for a selection of the alternative cases are shown in Figure 7. These cases compare costeffective $\mathrm{CO}_{2}$ transport distances for natural gas and coal power plants and ethanol and cement production plants under the base case with results for the alternative cases (a smaller total pond area in each facility, higher productivity, and 24-hour capture of $\mathrm{CO}_{2}$ to highlight the effects of these changes to the base-case parameters. Break-even distance results for $\mathrm{CO}_{2}$ gas transport from the ammonia production plant cases are similar to those from the ethanol production source. Results for the cement kiln cases fall between those for the ethanol production plant and the cement plant case, as in Figure 6.

Three general conclusions apply that are not necessarily intuitive. 1) Slightly longer break-even transport distances are associated with the smaller-area (202-ha) facility because less gas is needed to supply the microalgae. A smaller pipe system can be used and, since costs do not scale linearly with pipe diameter, a relatively less expensive transport system results. 2) Microalgae cultivation at higher productivity than the base case $\left(25 \mathrm{~g} \mathrm{~m}^{-2} \mathrm{~d}^{-1}\right)$ presents a challenge for $\mathrm{CO}_{2}$ transport because more gas and a higher-capacity, more expensive transport system are needed to provide sufficient $\mathrm{CO}_{2}$. The increased expense is associated mostly with the larger, more expensive pipes. Somewhat shorter break-even $\mathrm{CO}_{2}$ transport distances from the source to the algae cultivation system, therefore, result from this increase in productivity. 3) For the flue gases containing higher concentrations of $\mathrm{CO}_{2}$ (ethanol and ammonia), the 24-hr capture leads to even longer break-even distances (or less expensive transport systems), as expected. However, for the more dilute $\mathrm{CO}_{2}$ resources (power plant flue gases), 24-hr capture is not 
necessarily less expensive than 12-hr capture in the base case. The cost of operating the scrubber scales with flowrate [34], and the high cost of scrubbing the more voluminous, dilute $\mathrm{CO}_{2}$-containing gas can outweigh the savings on the capital cost of the pipeline. A comparison of the results for 12-hour and 24hour operation with the coal power plant as a source at an $8-\mathrm{km}$ distance from the 405 -ha ponds is shown as an example in Figure 8. 4) For natural gas power plants supplying $\mathrm{CO}_{2}$ to high-productivity $\left(25 \mathrm{~g} \mathrm{~m}^{-2} \mathrm{~d}\right.$ $\left.{ }^{1}\right)$ algal ponds, only a very short pipeline distance $(1.6 \mathrm{~km})$ gives a cost-effective solution for a 405 -ha algae pond. Thus, as improved technologies facilitate higher algal productivities, especially in warm, sunny locations, sources of dilute $\mathrm{CO}_{2}$ will become less desirable for co-location with commercial-scale microalgae production facilities. The steadily increasing annual $\mathrm{CO}_{2}$ emissions from natural gas facilities in the U.S., transitioning from coal $[12,37]$ are not as useful for high-productivity algae production as more concentrated sources of $\mathrm{CO}_{2}$.

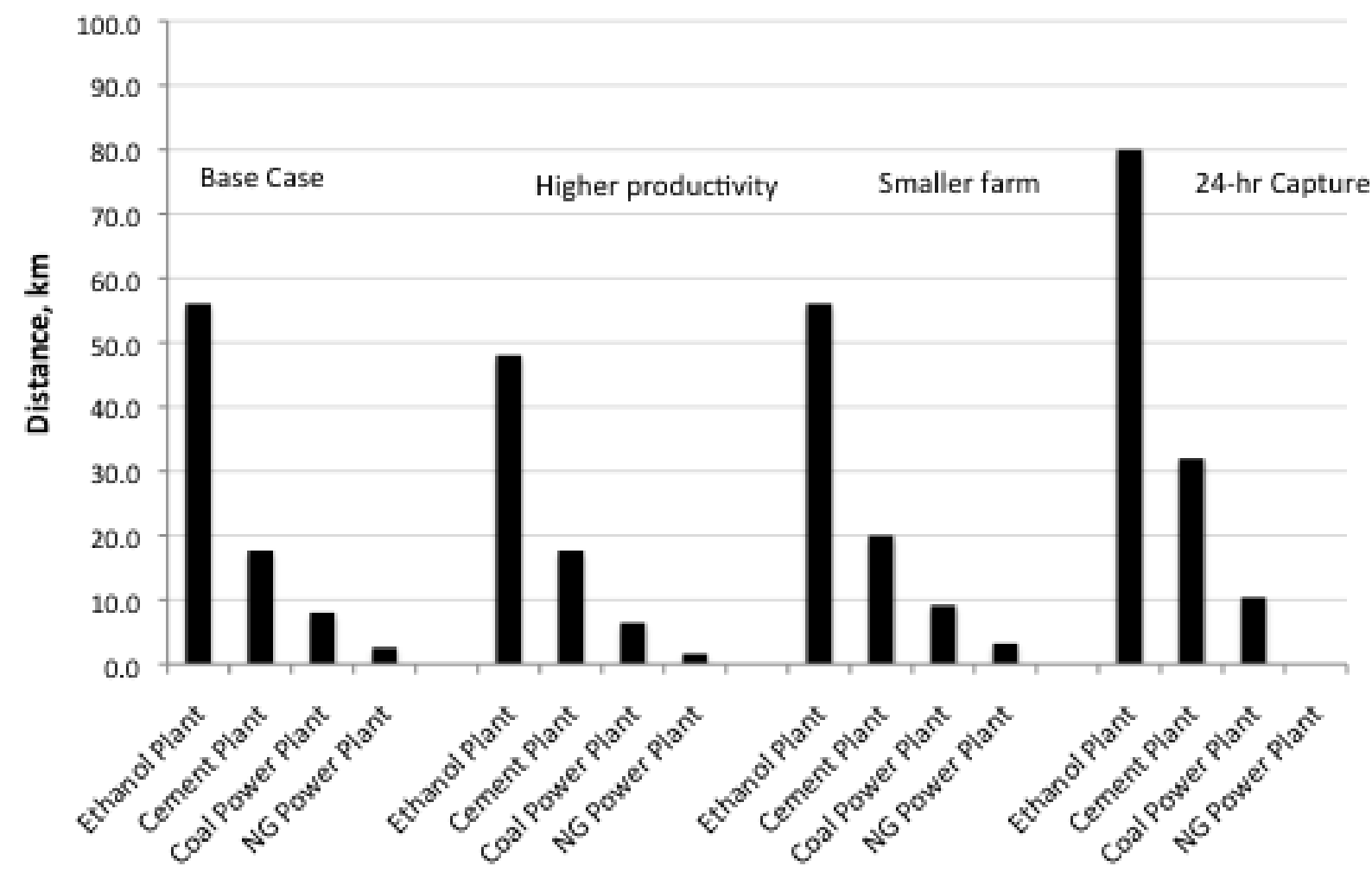

Figure 7. Cost-effective $\mathrm{CO}_{2}$ transport distances (relative to $\$ 44 /$ tonne $\mathrm{CO}_{2}$ ) for the resources considered under base-case, higher-productivity, smaller-facility, and 24-hr- $\mathrm{CO}_{2}$-capture conditions. These results correspond to a configuration that minimizes the electricity cost at the cost of greater capital expense. NG is natural gas. 


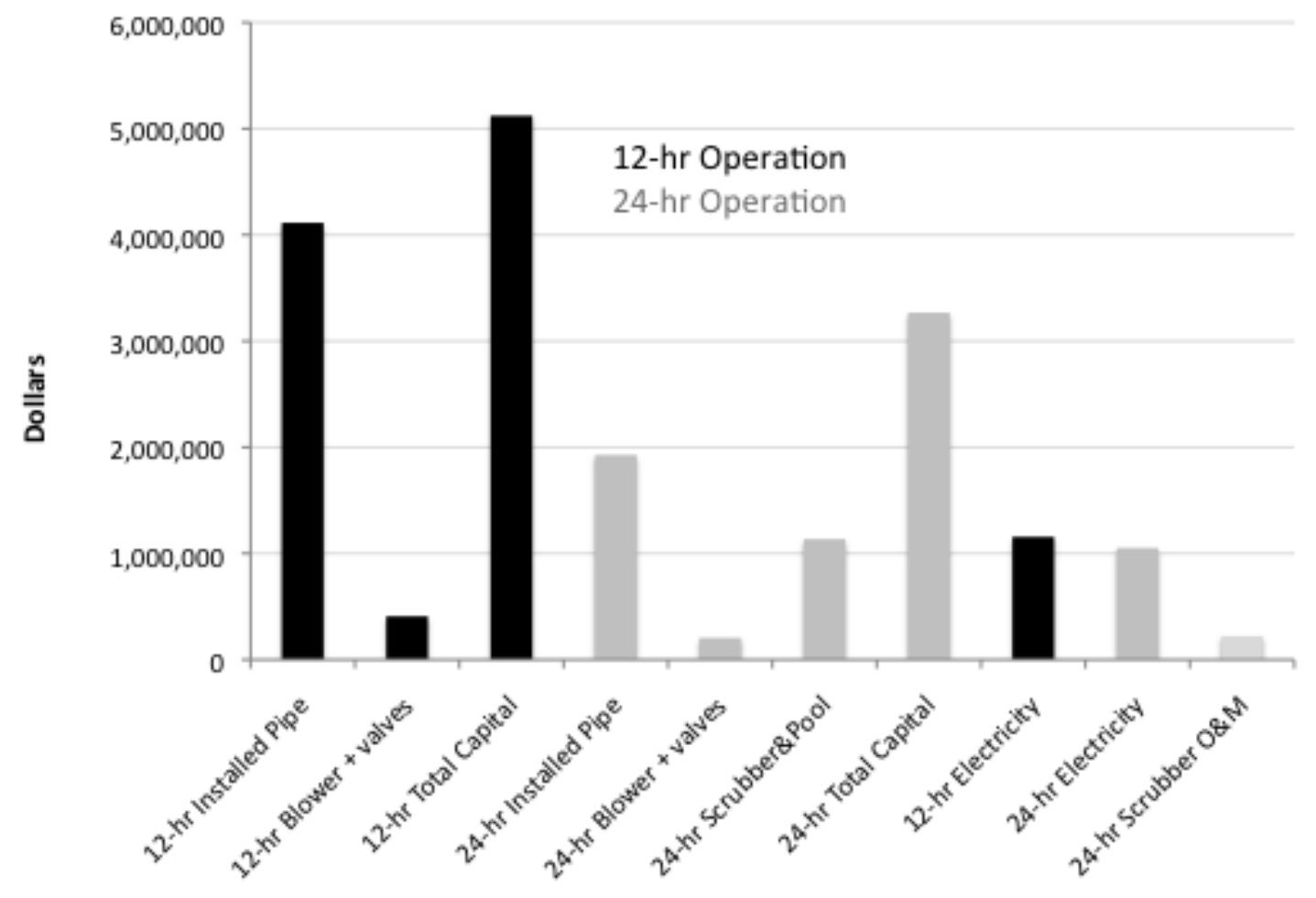

Figure 8. Comparison of costs for 12-hour base-case $\mathrm{CO}_{2}$ transport with the 24-hr $\mathrm{CO}_{2}$-capture case for a coal power plant at an 8-km distance. The difference between sum of the first two bars and the third is the approximate cost for a storage buffer for the gas as it reaches the ponds (see text).

The break-even $\mathrm{CO}_{2}$ transport distances (i.e., at which estimated annual costs of transport of $\mathrm{CO}_{2}$ equal annual costs of purchased $\mathrm{CO}_{2}$ ) range widely, from $1.6 \mathrm{~km}$ to $80 \mathrm{~km}$, depending on the assumptions for the case (Table 5). Distances are based on annual cost comparison results for all 24 cases and configurations that minimize either capital or electricity costs. While the lower bound distance $(1.6 \mathrm{~km})$ matches that assumed in Quinn et al. [15], the upper bound of $80 \mathrm{~km}$ for ethanol and ammonia plants with 24-hour $\mathrm{CO}_{2}$ storage is higher. Table 5 also shows the number of parallel pipes and the pipe diameter for each case at the break-even $\mathrm{CO}_{2}$ transport distance. 
Table 5. Cost-effective $\mathrm{CO}_{2}$ transport distances for the base case and cases with alternative algae cultivation parameters.

\begin{tabular}{|c|c|c|c|c|c|c|}
\hline & $\begin{array}{c}\text { Total Gas } \\
\text { flow, } \\
\mathrm{Nm}^{3} / \mathrm{hr}\end{array}$ & $\begin{array}{c}\text { Number } \\
\text { of } \\
\text { parallel } \\
\text { pipes }\end{array}$ & $\begin{array}{c}\text { Break-even } \\
\text { distance } \\
\text { minimizing } \\
\text { capital cost, } \\
\text { km }\end{array}$ & $\begin{array}{l}\text { Related Pipe } \\
\text { diameter, cm }\end{array}$ & $\begin{array}{c}\text { Break-even } \\
\text { distance } \\
\text { minimizing } \\
\text { electricity } \\
\text { usage, } \mathbf{k m}\end{array}$ & $\begin{array}{l}\text { Related Pipe } \\
\text { diameter, cm }\end{array}$ \\
\hline \multicolumn{7}{|l|}{ Base Case } \\
\hline Ethanol Plant & 5,106 & 1 & 40.0 & 23.6 & 56.0 & 43.2 \\
\hline Ammonia Plant & 5,263 & 1 & 40.0 & 21.6 & 52.8 & 43.2 \\
\hline Cement Kiln & 10,863 & 1 & 14.4 & 29.0 & 28.8 & 50.8 \\
\hline Cement Plant & 21,273 & 2 & 6.4 & 27.9 & 17.6 & 42.7 \\
\hline Coal Power Plant & 36,473 & 3 & 3.2 & 28.2 & 9.6 & 39.1 \\
\hline NG Power Plant & 102,127 & 8 & 1.8 & 28.7 & 2.6 & 32.8 \\
\hline \multicolumn{7}{|l|}{$\begin{array}{l}\text { Higher } \\
\text { Productivity }\end{array}$} \\
\hline Ethanol Plant & 9,672 & 1 & 32.0 & 27.7 & 48.0 & 53.1 \\
\hline Ammonia Plant & 9,968 & 1 & 32.0 & 27.7 & 48.0 & 53.1 \\
\hline Cement Kiln & 20,573 & 2 & 12.8 & 28.4 & 27.2 & 48.5 \\
\hline Cement Plant & 40,290 & 4 & 6.4 & 29.0 & 17.6 & 41.1 \\
\hline Coal Power Plant & 69,076 & 6 & 2.9 & 25.4 & 8.0 & 38.1 \\
\hline NG Power Plant & 193,421 & 10 & 1.6 & 34.0 & 1.6 & 34.0 \\
\hline \multicolumn{7}{|l|}{ Smaller Farm } \\
\hline Ethanol Plant & 2,553 & 1 & 48.0 & 16.3 & 56.0 & 32.0 \\
\hline Ammonia Plant & 2,632 & 1 & 48.0 & 16.3 & 56.0 & 32.0 \\
\hline Cement Kiln & 5,431 & 1 & 19.2 & 21.1 & 30.4 & 40.1 \\
\hline Cement Plant & 10,638 & 2 & 6.4 & 20.3 & 20.0 & 32.3 \\
\hline Coal Power Plant & 18,236 & 2 & 4.8 & 27.2 & 9.1 & 34.5 \\
\hline \multirow[t]{2}{*}{ NG Power Plant } & 51,063 & 8 & 2.1 & 21.8 & 3.2 & 24.9 \\
\hline & $\begin{array}{c}\text { Total Gas } \\
\text { flow, } \\
\mathrm{Nm}^{3} / \mathrm{hr}\end{array}$ & $\begin{array}{c}\text { Number } \\
\text { of } \\
\text { parallel } \\
\text { pipes }\end{array}$ & $\begin{array}{c}\text { Break-even } \\
\text { distance } \\
\text { minimizing } \\
\text { capital cost, } \\
\text { km } \\
\end{array}$ & $\begin{array}{l}\text { Related Pipe } \\
\text { diameter, cm }\end{array}$ & $\begin{array}{l}\text { Break-even } \\
\text { distance } \\
\text { minimizing } \\
\text { electricity } \\
\text { usage, km } \\
\end{array}$ & $\begin{array}{l}\text { Related Pipe } \\
\text { diameter, cm }\end{array}$ \\
\hline \multicolumn{7}{|l|}{ 24-hour Capture } \\
\hline Ethanol Plant & 2,553 & 1 & 52.8 & 16.3 & 80.0 & 40.4 \\
\hline Ammonia Plant & 2,632 & 1 & 52.8 & 16.3 & 80.0 & 40.4 \\
\hline Cement Kiln & 5,431 & 1 & 20.8 & 22.1 & 43.2 & 41.7 \\
\hline Cement Plant & 10,638 & 2 & 11.2 & 21.3 & 32.0 & 35.6 \\
\hline Coal Power Plant & 18,236 & 2 & 2.6 & 20.8 & 10.4 & 34.5 \\
\hline NG Power Plant & 51,063 & 8 & 0.0 & 18.3 & 0.0 & 18.3 \\
\hline
\end{tabular}

Notes: Base Case: Productivity of $13.2 \mathrm{~g} \mathrm{~m}^{-2} \mathrm{~d}^{-1}, 405 \mathrm{ha}, 12 \mathrm{hr} / \mathrm{day}$

Higher Productivity: $25 \mathrm{~g} \mathrm{~m}^{-2} \mathrm{~d}^{-1}$

Smaller Farm: 202 ha

24-hour capture: base case parameters

Overall, the results show a break-even $\mathrm{CO}_{2}$ transport distance (minimizing capital costs) of $40 \mathrm{~km}$ for waste gases containing $\mathrm{CO}_{2}$ at high concentration under the base case assumptions. For more dilute $\mathrm{CO}_{2}$ 
emissions from power plants under the same assumptions, the distances are much shorter, i.e., 1.8 to 3.2 $\mathrm{km}$, and they could be shorter still, once the costs of distributing dilute flue gas across the ponds, compared to costs for pure $\mathrm{CO}_{2}$, are considered. Some producers and pilot plants choose to co-locate facilities adjacent to $\mathrm{CO}_{2}$ sources to reduce costs [5-7]. Previous research had concluded that only shorter transport distances for $\mathrm{CO}_{2}$ transport to microalgae facilities would be cost-effective. For example, Benemann and colleagues estimated distances between 2.4 and $4.8 \mathrm{~km}$ for transporting $\mathrm{CO}_{2}$ from power plants, but for larger, 1000-ha microalgae cultivation facilities, where the gas demand is higher [11]. Quinn et al. [15] and Lundquist [16] also used a 4.8-km as their greatest co-location distance from a $\mathrm{CO}_{2}$ source. Our analysis suggests that transport distances for $\mathrm{CO}_{2}$-containing gas of greater than $4.8 \mathrm{~km}$ can be feasible under specific production assumptions, such as the use of $\mathrm{CO}_{2}$ of high purity, lowerproductivity cultivation systems $\left(13.2 \mathrm{~g} \mathrm{~m}^{-2} \mathrm{~d}^{-1}\right)$, and/or $24-\mathrm{hr} \mathrm{CO}_{2}$ storage.

Many annual carbon utilization efficiencies in the literature are measured or assumed to be lower than the assumption of $82 \%$ here. Recent reports are that sparging $\mathrm{CO}_{2}$ in traditional raceways results in a utilization efficiency of less than 50\% [38]. Some of the lower measured carbon utilization efficiencies in ponds or raceways are 25\% [39] and 26\% [40]. Wilson et al. [9] achieved a $44 \% \mathrm{CO}_{2}$ utilization efficiency in a photobioreactor. An $83 \%$ carbon utilization efficiency was achieved in an open pond system through the use of a bubble column to increase the area of contact for gas exchange [41]. Although the $\mathrm{CO}_{2}$ utilization efficiency was not employed directly as a sensitivity parameter in this study, the effect of changing the efficiency can be qualitatively considered by examining the variations of other parameters in this study that involve increased $\mathrm{CO}_{2}$ requirements. For example, a lower utilization efficiency would mean more $\mathrm{CO}_{2}$ required for all cases, just as higher productivity requires more $\mathrm{CO}_{2}$ than the base case. Thus, decreasing the $\mathrm{CO}_{2}$ utilization efficiency from $82 \%$ to $44 \%$ (as in [9]) might be expected to have the same effect on break-even $\mathrm{CO}_{2}$ transport distance as the approximate doubling of productivity considered here. However, the effect of chemical components of the flue gas on utilization efficiency would need to be studied, as well as the effect of closed versus open cultivation systems.

Additional costs that could vary from those assumed here are the cost of purchased $\mathrm{CO}_{2}$ (now and in the coming decades), the costs of materials used for pipelines (e.g., Quinn et al. [15] assumed concrete instead of PVC), the rate of amortized capital costs [42], the installation cost factor, and the local cost of electricity. An additional factor that could increase transport cost is a large variation in production with season; a larger pipe diameter or different system could be needed to accommodate the $\mathrm{CO}_{2}$ requirements for high productivity days. Costs of earth works were not included. Venteris et al. [12] highlight the importance of the distance to rail lines for determining material transport costs. Additional waste $\mathrm{CO}_{2}$ sources with different purities would have different costs as well. Maintenance costs may be more related to blowers and compressors than to capital costs, as assumed here. Carbon utilization policy incentives would also affect cost-effective $\mathrm{CO}_{2}$ transport distances and profitability [43]. Moreover, an additional factor that could increase transport cost is large variation in production with season; a larger pipe diameter or different system could be needed to accommodate the $\mathrm{CO}_{2}$ requirements for high productivity days.

Given the constraint of cost-effective waste $\mathrm{CO}_{2}$ transport distance that would be added to the constraint of land or location suitability (topography, water availability, climate), the question of how much algae could be grown at national scale using bulk flue gas transport is still an open one. In the 2016 Billion Ton Report, annual algae biomass potential was estimated at up to 42 million tonnes from Chlorella sorokiniana (a freshwater species) or at up to 78 million tonnes from Nannochloropsis salina (a saline water species) under mean national productivities close to that which was assumed here (i.e., current productivity assumptions) [1]. However, that analysis had some overlap between the supply areas of $\mathrm{CO}_{2}$ sources, did not fully consider short-term water availability, did not consider industrial $\mathrm{CO}_{2}$ sources, and did not consider some of the cost considerations in this analysis. Middleton et al. [18] identify vast areas in the U.S. where there is no access to waste $\mathrm{CO}_{2}$ at an "industrially relevant scale (i.e., $>25 \mathrm{kt} / \mathrm{yr}$ )." Pate et al. [44] argue that $\mathrm{CO}_{2}$ requirements, including siting considerations near waste $\mathrm{CO}_{2}$ streams, "appear to be the most significant challenge to algae biofuels scale-up," given the lack of a widely networked $\mathrm{CO}_{2}$ capture and transport infrastructure. And the purest industrial $\mathrm{CO}_{2}$ sources (e.g., ethanol plants) are not 
always located in high-productivity regions; in the 2016 Billion Ton Report the economic gains from increased productivity in warmer locations outweighed the $\mathrm{CO}_{2}$ cost savings differential from the higherpurity $\mathrm{CO}_{2}$ from ethanol plants [1]. More economical methods of carbon capture [45] may be available in the future, and these may obviate the cost-saving assumption here that $\mathrm{CO}_{2}$-containing gas must be transported by pipeline.

\section{CONCLUSIONS}

Cost savings can be achieved by co-locating open-pond microalgae production facilities near waste $\mathrm{CO}_{2}$ sources. The break-even $\mathrm{CO}_{2}$ transport distance (i.e., distance at which the annualized cost of transporting $\mathrm{CO}_{2}$ to the facility is equivalent to the cost to purchase $\mathrm{CO}_{2}$ ) depends primarily on the concentration of $\mathrm{CO}_{2}$ in the waste stream and on the amount of microalgae biomass that requires the $\mathrm{CO}_{2}$, which is determined by algae productivity and facility size. Additionally, trade-offs between capital and operating costs based on pipe and blower sizing affect the overall cost-effectiveness and break-even co-location distances. This study shows that the concentration of in flue gas also is an important determinant of cost and cost-effective transport. Sources of lower concentration $\mathrm{CO}_{2}$, such as natural gas power plants, may have limited utility for co-location with algae cultivation, as shown here from a $\mathrm{CO}_{2}$ transport cost perspective, and as shown by Rickman et al. [10] from the perspective of mitigation of $\mathrm{CO}_{2}$ emissions. This study also shows that potential utilization of nighttime $\mathrm{CO}_{2}$ storage is an important contributor to cost reduction and that as productivity increases, the scaling up of pipelines may reduce the cost-effective $\mathrm{CO}_{2}$ transport distances. Further study is needed to integrate these costs with techno-economic analyses, to include costs of distributing $\mathrm{CO}_{2}$ to the algae farm (which should be lower for smaller farms and purer sources of $\mathrm{CO}_{2}$ ) and to consider tradeoffs between the cost savings of scaling up most system components and the nonlinear scaling, higher costs of transporting higher quantities of $\mathrm{CO}_{2}$-containing gas. As carbon policy evolves, an awareness of this utilization potential by algae will be important for both emitting industries and the for national assessments of algae biomass potential and costs.

\section{REFERENCES}

1. R. Efroymson, A. Coleman, M. Wigmosta, S. Schoenung, S. Sokhansanj, M. Langholtz, R. Davis, Microalgae, in: M.H. Langholtz, B.J. Stokes, L.M. Eaton (Leads), 2016 Billion-Ton Report: Advancing Domestic Resources for a Thriving Bioeconomy, Volume 1: Economic Availability of Feedstocks, ORNL/TM-2016/160, U.S. Department of Energy and Oak Ridge National Laboratory, Oak Ridge, TN, 2016, pp. 243-312.

2. A.D. Vuppaladadiyam, J. G. Yao, N. Florin, A. George, X. Wang, L. Labeeuw, Y. Jiang, R.W. Davis, A. Abbas, P. Ralph, P.S. Fennell, M. Zhao, Impact of flue gas compounds on microalgae and mechanisms for carbon assimilation and utilization. ChemSusChem Reviews 11 (2018) 334-355.

3. R. Davis, J. Markham, C. Kinchin, N. Grundl, E.C.D. Tan, D. Humbird, Process Design and Economics For the Production Of Algal Biomass: Algal Biomass Production In Open Pond Systems And Processing Through Dewatering For Downstream Conversion. NREL/TP-5100-64772, National Renewable Energy Laboratory, Golden, CO, 2016.

4. K. Kloosterman. Food and fuel from greenhouse gas? Israel 21c, 2011, https://www.israel21c.org/food-and-fuel-from-greenhouse-gas/

5. M.H. Wilson, J. Groppo, A. Placido, S. Graham, A.A. Morton III, E. Santillan-Jiminez, A. Shea, M. Crocker, C. Crofcheck, R. Andrews, $\mathrm{CO}_{2}$ recycling using microalgae for the production of fuels. Appl. Petrochemical Res. 4 (2014) 41-53.

6. H. Jessen, Green expectations. Ethanol Producer Magazine. March 9, 2015, http://www.ethanolproducer.com/articles/12005/green-expectations

7. D. Hazlebeck, Open-raceway algal pond operations, Algae Biomass Summit, San Diego, CA, September 29-October 2, 2014. 
8. X. Zhang, Microalgae removal of $\mathrm{CO}_{2}$ from flue gas, 2015, IEA Clean Coal Centre. London. https://www.usea.org/sites/default/files/042015 Microalgae\%20removal\%20of\%20CO2\%20from\%2 Oflue\%20gas_ccc250.pdf

9. M.H. Wilson, D.T. Mohler, J.G. Groppo, T. Grubbs, S. Kesner, E. M. Frazar, A. Shea, C. Crofcheck, M. Crocker, Capture and recycle of industrial $\mathrm{CO}_{2}$ emissions using microalgae. Appl. Petrochem. Res. 6 (2016) 279-293.

10. M. Rickman, J. Pellegrino, J. Hock, S. Shaw, B. Freeman, Life-cycle and techno-economic analysis of utility-connected algae systems. Algal Res. 2 (2013)59-65.

11. J.R. Benemann, W.J. Oswald., Systems and Economic Analysis Of Microalgae Ponds For Conversion Of $\mathrm{CO}_{2}$ To Biomass, DOE/PC/93204-T5, University of California, Berkeley, Berkeley, CA, 1996.

12. E.R. Venteris, R.L. Skaggs, M.S. Wigmosta, A.M. Coleman, A national-scale comparison of resource and nutrient demands for algae-based biofuel production by lipid extraction and hydrothermal liquefaction. Biomass Bioenergy 64 (2014) 276-290.

13. J.C. Quinn, R. Davis, The potentials and challenges of algae based biofuels: A review of the technoeconomic, life cycle, and resource assessment modeling, Bioresource Technol. 184 (2015) 444-452.

14. C.M. Beal, L.N. Gerber, D.L. Sills, M.E. Huntley, S.C. Machesky, M.J. Walsh, J.W. Tester, I. Archibald, J. Granados, C.H. Greene, Algal biofuel production for fuels and feed in a 100-ha facility: A comprehensive techno-economic analysis and life cycle assessment, Algal Res., 10 (2015) 266279.

15. J.C. Quinn, K.B. Catton, S. Johnson, T.H. Bradley, Geographical assessment of microalgae biofuels potential incorporating resource availability. 6 (2013) 591-600.

16. T.J. Lundquist, I.C. Woerta, N.W.T. Quinn, J.R. Benemann, A Realistic Technology and Engineering Assessment of Algae Biofuel Production, Energy Biosciences Institute, University of California, Berkeley, Berkeley, CA, 2010.

17. NATCARB, National Carbon Sequestration Database and Geographic Information System, NATCARB Sources 2012, v.1501, 2015. U.S. Department of Energy National Energy Technology Laboratory, Morgantown, WV, https://edx.netl.doe.gov/dataset/natcarb-co2sources-v1501archived/resource/d4eac20d-a979-4c29-9c91-cfeb9556533d

18. R.S. Middleton, A.F. Clarens, X. Liu, J.M. Bielicki, J.S. Levine, $\mathrm{CO}_{2}$ deserts: implications of existing $\mathrm{CO}_{2}$ supply limitations for carbon management. Environ. Sci. Technol. 48 (2014) 11713-11720.

19. USEPA, Air Emission Factors and Quantification, AP-42: Compilation of Air Emission Factors, 2009.

20. ICM, Ethanol Production Process. ICM, Inc., Colwich, KS, 2017, http://www.icminc.com/innovation/ethanol/ethanol-production-process.html

21. Institute for Industrial ProductivityAmmonia, Industrial Efficiency Technology Database, 2017, http://ietd.iipnetwork.org/content/ammonia

22. NRMCA, Concrete $\mathrm{CO}_{2}$ Fact Sheet, NRMCA Publication Number 2PCO2, National Ready Mixed Concrete Association, Silver Spring, MD, 2012.

23. R. Davis, D. Fishman, E.D. Frank, M.S. Wigmosta, Renewable Diesel From Algal Lipids: An Integrated Baseline For Cost, Emissions, And Resource Potential From a Harmonized Model, ANL/ESD/12-4, NREL/TP-5100-55431, PNNL-21437, Argonne National Laboratory, Argonne, IL, National Renewable Energy Laboratory, Golden, CO, Pacific Northwest National Laboratory, Richland, WA, 2012.

24. NATCARB, A National Look at Carbon Sequestration, 2014. http:natcarbviewer.com

25. D. Hazlebeck, Global Algae Innovations, personal communication, June 2016.

26. H. Aghajani, J.M. Race, B. Wetenhall, E. Sanchez Fernandez, M. Lucquiaud, H. Chalmers, On the potential for interim storage in dense phase $\mathrm{CO}_{2}$ pipelines. International Journal of Greenhouse Gas Control 66 (2017) 276-287.

27. SPE, PetroWiki, Pressure Drop Evaluation Along Pipelines, Society of Petroleum Engineers,: Richardson, TX, 2015. http://petrowiki.org/Pressure_drop_evaluation_along_pipelines\#Pressure_drop_for_gas_flow. Accessed September 2015. 
28. M.S. Peters, K.D. Timmerhause, R.E. West, Plant Design and Economics for Chemical Engineers, fifth Ed.), McGraw Hill, New York, 2003.

29. W.S. Janna, Design of Fluid Thermal Systems, fourth ed., Cengage Learning, Stamford, CT, 2015.

30. Atlas Copco, Compressed Air Manual, seventh ed., Atlas Copco Airpower NV, Wilrijk, Belgium, 2010.

31. D. Humbird, R. Davis, L. Tao, C. Kinchin, D. Hsu, A. Aden, P. Schoen, J. Lukas, B. Olthof, M. Worley, D. Sexton, and D. Dudgeon, Process Design and Economics for Biochemical Conversion of Lignocellulosic Biomass to Ethanol: Dilute-Acid Pretreatment and Enzymatic Hydrolysis of Corn Stover, NREL/TP-5100-47764, National Renewable Energy Laboratory, Golden, CO, 2011.

32. R. Davis, L. Tao., E.C.D. Tan, M.J. Biddy, G.T. Beckham, C. Scarlata, J. Jacobson, K. Cafferty, J. Ross, J. Lukas, D. Knorr, P. Schoen, Process Design and Economics for Conversion of Lignocellulosic Biomass to Hydrocarbons: Dilute-Acid and Enzymatic Deconstruction of Biomass to Sugars and Biological Conversion of Sugars to Hydrocarbons, National Renewable Energy Laboratory, NREL/TP-5100-60223, Golden, CO, 2013.

33. R. Davis, L. Tao, C. Scarlata, E.C.D. Tan, Process Design and Economics for the Conversion of Lignocellulosic Biomass to Hydrocarbons: Dilute-Acid and Enzymatic Deconstruction of Biomass to Sugars and Catalytic Conversion of Sugars to Hydrocarbons, NREL/TP-5100-62498, National Renewable Energy Laboratory, Golden, CO, 2015.

34. USEPA, Packed-Bed/Packed-Tower Wet Scrubber, Air Pollution Control Technology Fact Sheet, EPA-452/F-03-015, U.S. Environmental Protection Agency, 2015. https://www3.epa.gov/ttncatc1/dir1/fpack.pdf

35. EPRI Technical Assessment Guide ${ }^{\mathrm{TM}}(T A G \AA) — P o w e r$ Generation and Storage Technology Options, Electric Power Research Institute, Palo Alto, CA, 2013.

36. P. Luckow, E.A. Stanton, S. Fields, B. Biewald, S. Jackson, J. Fisher, R. Wilson, 2015 Carbon Dioxide Price Forecast, Synapse Energy Economics, Inc., Cambridge, MA, 2015.

37. EIA, U.S. energy-related CO2 emissions expected to rise slightly in 2018, remain flat in 2019. 2018https://www.eia.gov/todayinenergy/detail.php?id=34872

38. BETO, Algae Cultivation for Carbon Capture and Utilization Workshop Summary Report, Orlando, FL, May 2017, Bioenergy Technologies Office, Office of Energy Efficiency \& Renewable Energy, U.S. Department of Energy, https://www.energy.gov/sites/prod/files/2017/09/f37/algae cultivation for carbon capture and utili zation workshop.pdf

39. C.M. Beal, R.E. Hebner, M.E. Webber, R.S. Ruoff, A.F. Seibert, C.W. King, Comprehensive evaluation of algal biofuel production: Experimental and target results. Energies 5 (2012) 1943-1981.

40. N.M. Langley, S.T. Harrison, R.P. van Hille, A critical evaluation of CO2 supplementation to algal systems by direct injection. Biochemical. Eng. J. 68 (2012) 70-75.

41. R. Putt, M. Singh, S. Chinnasamy, D.C. Das, An efficient system for carbonation of high-rate algae pond water to enhance $\mathrm{CO}_{2}$ mass transfer. Bioresource Technology 102 (2011) 3240-3245.

42. P.K. Campbell, T. Beer, D. Batten, Life cycle assessment of biodiesel production from microalgae in ponds. Bioresource Technology 102 (2011) 50-56.

43. R.A. Efroymson, V.H. Dale, M.H. Langholtz, Socioeconomic indicators for sustainable design and commercial development of algal biofuel systems. GCB Bioenergy 9 (2017) 1005-1023.

44. R.C. Pate, Resource requirements for the large-scale production of algal biofuels. Biofuels 4 (2013) 409-435.

45. K. Schipper, S. van der Gijp, R. van der Stel, E. Goetheer, New methodologies for the integration of power plants with algae ponds. Energy Procedia 37 (2013) 6687-6695.

46. R. Davis, A. Aden, P.T. Pienkos, Techno-economic analysis of autotrophic microalgae for fuel production, Appl. Energy 88 (2011) 3524-3531. 